\title{
ANTIULCER AGENTS: A PHARMACOLOGICAL UPDATE OF THE PAST TEN YEARS
}

\author{
SUDIP KUMAR MANDAL ${ }^{1 *}$, SUBHOJIT DAWN ${ }^{1}$, ANINDYA BOSE ${ }^{2}$
}

${ }^{1}$ Department of Pharmaceutical Chemistry, Dr. B. C. Roy College of Pharmacy and Allied Health Sciences, Durgapur, West Bengal, India. ${ }^{2}$ Department of Pharmaceutical Analysis, School of Pharmaceutical Sciences, Siksha 0 Anusandhan University, K8 Kalinga Nagar, Bhubaneswar, Odisha, India. Email: gotosudip79@gmail.com

Received: 17 June 2019; Revised and Accepted: 13 June 2019

\begin{abstract}
New antiulcer substances are still vitally necessary for the people of countries such as India and South Africa to avoid high cost of the most prescribed marketed anti-ulcer drugs (proton-pump inhibitors). New candidate against gastric ulcer is also necessary to avoid the potential problem (enterochromaffin-like cell hyperplasia may be induced) associated with the long-term use of synthetic proton-pump inhibitors. However, the search for the novel entity against ulceration is challenging because of the complexity of the ulcer process and its role in host defense to infections. Nature is the source of remedies for the humankind. Among the different biological activities of the natural products that have been published till date, antiulcer is one of the most reported effects. Some single natural products such as curcumin, 1-hydroxy-3,7,8-trimethoxyxanthone, cinnamic acid, thymol, epoxycarvone, and menthol; single synthetic products such as, 4,6-diaryl-3, 4-dihydropyrimidin-2(1H)-thiones, 1,4-dihydropyrimidine derivatives, and dihydropyrimidinone and piperidine hybrids; plant products such as Aloe vera, Mangifera indica, Zingiber officinale, Azadirachta indica, Psidium guava, Carica papaya, Panax ginseng, Terminalia chebula, Ocimum sanctum, Daucus carota, and Mimosa pudica, Alpinia galangal; nutraceuticals such as garlic, cauliflower, banana, honey, cucumber, and cod liver oil with anti-ulcer effects have been discussed in this review. A complete review of literature was conducted using different databases on ScienceDirect, Scopus, PubMed, and Google Scholar. This review is a genuine attempt to explore the past 10 years' pharmacological update of some antiulcer agents.
\end{abstract}

Keywords: Bioactive agents, Single molecules, Plant products, Nutraceuticals, Antiulcer, Gastro protective.

(C) 2019 The Authors. Published by Innovare Academic Sciences Pvt Ltd. This is an open access article under the CC BY license (http://creativecommons. org/licenses/by/4. 0/) DOI: http://dx.doi.org/10.22159/ajpcr.2019.v12i8.34175

\section{INTRODUCTION}

Ulcer is a very conventional disease in the world. Statistics from all sources indicate $10 \%$ or more of adult population are affected within their life time. Peptic ulcer disease refers to the defect in the mucosal surface of the stomach or duodenum called peptic and duodenal ulcer. Peptic ulcer occurs more often in individuals from 20 to 60 years of age with males. The symptoms of peptic ulcer include abdominal pain, nausea, epigastric gnawing, heartburn, acid eructations, hemorrhage, anemia, weight loss, and vomiting [1,2]. In general, gastric ulcers are the results of an imbalance in the equilibrium between mucosal damaging (acid and pepsin) and protecting (mucous, PGE2, and PGI2) mechanism of the gastric mucosa. Acid secretion is a physiologically important function of the stomach, as gastric acid $(\mathrm{HCl})$ induces pepsinogen activator that helps to initiate digestive process [3]. Several factors are responsible for gastric ulcers such as consuming several marketed nonsteroidal anti-inflammatory drugs (nimesulide and aceclofenac), steroidal drugs (prednisolone), tobacco smoking, psychological stress, alternative lifestyle, and alcohol abuse [4]. The major causative factor is inflammation due to Helicobacter pylori, which damages the gastric mucosa via excessive acid secretion from parietal cells by increasing the parietal cell mass due to its inflammatory effects on parietal cells of gastric mucosa [5]. If supposed to understand that $H$. pylori was the causative agent for an ulcer, numerous investigation and animal models were established to come up with the mechanism via which H. pylori established itself in gastric environment and is responsible for the pathogenesis of gastric ulcer. Although more than half of the population of the world is affected by $H$. pylori, only $5-10 \%$ develops ulcer $[6,7]$.

\section{AGENTS WITH ANTI-ULCER ACTIVITIES}

\section{Natural single molecules}

Curcumin

Curcumin is a polyphenol isolated from the rhizome of Curcuma longa. It is used as ayurvedic medicine against peptic ulcer and duodenal ulcer [8]. Water- and fat-soluble extracts of curcumin show antioxidant activity compare to Vitamins $\mathrm{C}$ and E. Ulcer protective effect of curcumin in rat liver injury induced by ethanol was reported [9]. The curcumin acts on the gastroprotective factors such as endogenous prostaglandins, sulfhydryl compounds, nitric oxide (NO), hydrogen sulfide $\left(\mathrm{H}_{2} \mathrm{~S}\right)$ and carbon monoxide (CO) to cooperate in the mechanism of gastric mucosal integrity.

\section{1-Hydroxy-3,7,8-trimethoxyxanthone}

1-hydroxy-3,7,8-trimethoxyxanthone, a naturally occurring compound, was isolated from the stem bark of Anthocleista vogelii belong to the family of Loganiaceae [11]. The anti-ulcer activity of methanolic extract of the stem bark of $A$. vogelii plant was shown in indomethacin-induced ulcer model $1-5 \mathrm{mg} / \mathrm{kg}$, giving orally. This molecule showed gastric cytoprotective and antisecretory activities significantly $(\mathrm{p}<0.01)$ prevented the formation of gastric lesions induced by indomethacin. As a result, this molecule increased mucus secretion significantly in a dose-dependent manner in all experimental models [12] and showed direct mucosal protection similar to that of prostaglandin analogs such as misoprostol [13].

\section{Cinnamic acid}

Cinnamic acid is an active ingredient in cinnamon, obtained from the inner bark of several tree species from the genus Cinnamomum, and has shown anti-ulcer activity. In a recent studies, protection against ulcer and gastritis by Cinnamomi ramulus bark extract and cinnamic acid was shown in acid neutralizing capacity against $H$. pylori [14]. Likewise, cinnamic acid (100 mg/kg) significantly inhibited (42.8\%) HCl-/ethanolinduced gastric lesions and increased mucus contents in rats [15]. The bark extract Cinnamomum cassia exhibited protective effects against gastric damage in vivo through stimulation of mucus secretion; as a result, cinnamic acid is responsible for anti-ulcer activity [16].

Thymol

Thymol is a monocyclic monoterpene compound isolated from Thymus vulgaris $\mathrm{L}$. The water extract of this herb protected gastric mucosa with 
the oral doses of $0.08 \mathrm{mg} / \mathrm{kg}$ when evaluated in Rainsford's cold stress ulcer model [17]. The mechanisms involved for this activity are opening $\mathrm{K}_{\text {ATP }}$ channels, activation of the NOS pathway, stimulation of mucus production, and alteration of endogenous prostaglandin production; as a result, thymol is responsible for anti-ulcer activity [18].

\section{Epoxycarvone}

Epoxycarvone is a monocyclic monoterpene compound isolated from Carum carvi L [16]. Recently, the gastroprotective activity of epoxycarvone studied against ethanol and indomethacin induced ulcer in rats, with the doses of $10-50 \mathrm{mg} / \mathrm{kg}$ orally [19]. However, this effect did not involve antisecretory activity or increased synthesis of NO and prostaglandins [20].

Menthol

Menthol is a cyclic monoterpene alcohol, isolated from Mentha piperita L, which is commonly known as peppermint [21]. In recent studies, oral administration of menthol (50 mg/kg) produced a substantial protective action on the gastric mucosa tested against ethanol and indomethacin in rats. The protective mechanism appears to involve increased production of mucus and PGE2 and stimulation of $\mathrm{K}_{\text {ATP }}^{+}$channels but not the activation of calcium ion channels or the production of NO. As a result, menthol significantly reduced total acid output and decreased ulcer index, and finally, menthol is responsible for anti-ulcer activity [22].

\section{Synthetic single molecules}

\section{4,6-diaryl-3,4-dihydropyrimidin-2(1H)-thiones}

4,6-diaryl-3,4-dihydropyrimidin-2(1H)-thiones are synthetic compounds, and the anti-ulcer activity of these compounds was shown in aspirininduced ulcer model in albino rats with the doses of $100 \mathrm{mg} / \mathrm{kg}$ orally, and omeprazole was used as standard with the doses of $20 \mathrm{mg} / \mathrm{kg}$ by inhibiting $\mathrm{H}^{+} \mathrm{K}^{+}$-ATPase pump. As a result, gastric acid secretion and ulcer index were reduced. The results proved that 4,6-diaryl-3,4-dihydropyrimidin-2(1H)thiones were therapeutically effective to treat gastric ulcer [23].

\section{1,4-dihydropyrimidine derivatives}

1,4-dihydropyrimidine derivatives are synthetic compounds, and the anti-ulcer activity of these compounds was shown in ethanolinduced ulcer model in albino rats with the doses of $20 \mathrm{mg} / \mathrm{kg}$ orally, and omeprazole was used as standard with the doses of $20 \mathrm{mg} / \mathrm{kg}$ by inhibiting $\mathrm{H}+\mathrm{K}+\mathrm{ATPase}$ pump; as a result, gastric acid secretion was reduced [24]. These compounds reduced the volume of gastric acid, $\mathrm{pH}$, free acidity, total acidity, and ulcer index. Substitution of methoxy group increased the anti-ulcer potential of the compounds [25].

\section{Dihydropyrimidinone and piperidine hybrids}

The anti-ulcer activity of dihydropyrimidinone and piperidine hybrids was shown in indomethacin-induced ulcer model in albino Wistar rats by inhibiting $\mathrm{H}^{+} \mathrm{K}^{+}$ATPase pump [26]. Compounds were given at a dose of $12.5,25$, and $50 \mathrm{mg} / \mathrm{kg}$. As a result, gastric acid secretion and ulcer index were reduced [27]

\section{Plant products}

Aloe vera

Aloe has been used for millennium which is more like a cactus plant, growing in dry climates, containing compounds such as amino acids, saponins, enzymes, anthraquinones, flavonoids, gallic acid, and vitamins [28]. The anti-ulcer activity of leaf gel extract of Aloe was shown in indomethacin-induced ulcer model with the doses of 50, 100, and $150 \mathrm{mg} / \mathrm{kg}$ by mucus-secreting mechanism. As a result, A. vera reduced gastric secretion, total acid output, and ulcerative index and increased mucus production [29]. A. vera group was significantly reduced compared with intact group $(\mathrm{p}<0.05)$, but gastric ulcer group had no significant difference with intact and $A$. vera group [30].

\section{Mangifera indica}

M. indica belongs to the family Anacardiaceae. This plant contains various polyphenolic compounds among which mangiferin is most active. The petroleum ether $(250 \mathrm{mg} / \mathrm{kg})$ and ethanol $(250 \mathrm{mg} / \mathrm{kg})$ plant leaf extracts significantly reduced ulcer index and showed antiulcer activity [31]. Another finding provides evidence that mangiferin shows gastroprotective action against gastric injury through antioxidant mechanism of action [9].

\section{Zingiber officinale}

Z. officinale belongs to the family of Zingiberaceae. It chemically contains resin. In recent studies, the aqueous extract of these plants (200 and $400 \mathrm{mg} / \mathrm{kg}$ ) was applied in indomethacin-induced gastric damage in rats, and a significant percentage inhibition of gastric ulcer was observed [32]. Powdered rhizome of ginger root has been used as a traditional remedy for gastrointestinal complaints including in treating peptic ulceration [33].

\section{Azadirachta indica}

A. indica is generally known as neem, belonging to the family Meliaceae. The aqueous extracts of neem leaves were investigated in rats with the doses of 10,40 , or $160 \mathrm{mg} / \mathrm{kg}$ body weight and prevent ulcer by blocking acid secretion through inhibition of $\mathrm{H}+-\mathrm{K}+\mathrm{ATPase}$ pump [34]. In a recent study, ethanolic extract of $A$. indica $(400 \mathrm{mg} / \mathrm{kg}$ ) was investigated in pylorus ligation ulcer model, and there was a significant reduction in gastric volume, free acidity, total acidity, combined acidity, and ulcer index [35].

\section{Psidium guajava}

P. guajava is commonly known as guava, belonging to the family of Myrtaceae. It contains tannins, phenols, saponins, vitamins, fibers, flavonoids, essential oils, fatty acids, etc [36]. Anti-ulcer activity was performed, with the methanolic extract of Psidium guava being given orally with the doses of (500 and $1000 \mathrm{mg} / \mathrm{kg}$ ) against ethanol-induced ulcer in rats. As a result, the significant reduction occurred in ulcer parameters, thereby affirming the gastroprotective activity [37]. The ulcer-healing properties of $P$. guava might be due to its antisecretory property [38].

\section{Carica papaya}

C. papaya belongs to the family Caricaceae. The fruit of this plant contains papain which is responsible for anti-ulcer activity [9]. Hydroalcoholic extract of unripe fruit of c. papay was evaluated in pylorus ligation induced ulcer model and the result showed reduction in the ulcer index [39]. In a recent study, the aqueous seed extract of this plant with the doses 50 and $100 \mathrm{mg} / \mathrm{kg}$ intraperitoneally was evaluated in rats against ethanolinduced gastric ulcer which protected the gastric mucosa against ethanol effect by significantly $(\mathrm{p}<0.001)$ decreased ulcer index, as a result reducing the gastric juice volume and gastric acidity [40].

\section{Panax ginseng}

P. ginseng belongs to the family of Araliaceae. It is commonly known as Ginseng. It is chemically composed of ginsenosides, amino acids, alkaloids, phenols, proteins, polypeptides, and Vitamins B1 and B2 [41]. In a recent study, methanolic extract was isolated from this plant and administered in the rats with the doses of 150 and $300 \mathrm{mg} / \mathrm{kg}$ and tested against ulcer induced by pylorus ligation by different models which significantly reduced the gastric acid secretion and increased in mucus secretion from the stomach [42]. This effect was observed not only after oral but also after systemic administration, suggesting a non-local effect. However, these plants blocked histamine-induced acid secretion [43].

\section{Terminalia chebula}

T. chebula belongs to the family of Combretaceae. It is commonly known as Myrobalan. It is chemically composed of triterpenoids, tannins, phenolic compounds, and flavonoids. Hydroalcoholic extract was isolated from the fruit of this plant and was administered in rats with the doses of $250 \mathrm{mg} / \mathrm{kg}$, tested against ulcer induced by aspirin, ethanol, and cold-restraint stress by ulcer model. As a result, T. chebula 
extract increased mucus production in aspirin- and ethanol-induced ulcer models and showed antisecretory activity in pylorus-ligated model leading to a reduction in the total volume of gastric juice and increased gastric $\mathrm{pH}[44,45]$.

\section{Ocimum sanctum}

O. sanctum belongs to the family of Lamiaceae. The fixed oil was isolated from this plant and was administered in the rats with the doses of 1,2 , and $3 \mathrm{~mL} / \mathrm{kg}$ intraperitoneally and was tested against ulcer induced by aspirin, indomethacin, and alcohol ulceration. It reduced the ulcer index in a dose-dependent manner compare to reference drug omeprazole $(\mathrm{p}<0.05)$ [46]. The ethanolic leaf extract of 0 . sanctum also showed anti-ulcerogenic activity. The fixed oil significantly possessed anti-ulcer activity due to its lipoxygenase inhibitory, histamine antagonistic, and antisecretory effects [47]. O. sanctum and its active constituents were therapeutically effective to treat gastric ulcer [48].

\section{Daucus carota}

One study was performed to search the activity of the juice of D. carota roots against ulcer, induced by pylorus ligation method in rats. The juice was compared with standard drug ranitidine. The juice of $D$. carota roots exhibited a considerable reduce in the acid volume, free acidity, etc. Finally, the juice was found to show powerful antisecretory effects by reducing the acid output [49]. The anti-ulcer activity of fresh juice extracts of $D$. carota roots also reported by Khatib et al. They evaluated the anti-ulcer activity using the parameters such as volume of gastric section, $\mathrm{pH}$, and ulcer index [50].

\section{Mimosa pudica}

M. pudica belongs to the family of Fabaceae, commonly known as "touch me not" and known as Lajjalu in Ayurveda. Different solvent extracts of M. pudica were used orally to exhibit anti-ulcer activity in albino rats, where ulcer was induced with alcohol and aspirin. The study showed that the plant has good anti-ulcer activity when compared with ranitidine. The ethanolic leave extract of this plant may be useful as a natural antioxidant in the treatment of ulcer. Alkaloid mimosine is active compound of this plant which was considered for anti-ulcer activity [51,42].

\section{Alpinia galangal}

A. galanga belongs to the Zingiberaceae family and is commonly known as greater galangal. The anti-ulcer and cytoprotective activity of A. galanga was reported very recently.

The cytoprotective activity of this plant was exhibited by ethanolic extract of rhizome of this plant via significant reduction of gastric acid secretion in rats, where gastric mucosal damage was induced by pyloric ligation method. The ethanolic seed extract of $A$. galangal also showed cytoprotective activity. The active ingredients, 1'-acetoxychavicol acetate and 1'-acetoxyeugenol acetate, which were actually played a role in cytoprotective activity, were isolated from the ethanolic extracts of rhizome and seed. This cytoprotective activity may be responsible for the anti-ulcer activity [52-55].

\section{Nutraceuticals}

Garlic

Garlic is a very common food material used, especially in India and China, obtained from Allium sativum belonging to the family Liliaceae. According to Ayurveda, the mustard or coconut oil in which garlic has been fried was a proper nutrient to avoid maggots infesting ulcer, ulcerated surface, and wounds, etc [56]. In a recent study, the garlic juice mixed with 3 or 4 parts of distilled water was administered at the doses of 250 and $500 \mathrm{mg} / \mathrm{kg}$ orally in rats against cystamine-induced gastric ulcer and significantly increased the healing activities [57]

\section{Cauliflower}

Cauliflower is a commonly available vegetable in the market, a big source of Vitamin C, fiber, and sulforaphane. It destroyed the H. pylori bacteria which was responsible for stomach ulcer. The indole-3-carbinol, a phytochemical compound found in the cauliflower, possessed anti-ulcer activity alone or combination with omeprazole on aspirin-induced gastric ulcer in male albino rats [58]. The methanolic extract of Brassica oleracea also reduced ulcer index $(\mathrm{p}<0.05)$ in the dose $0.50 \mathrm{mg} / \mathrm{kg}$ [59].

Banana

The benefits of banana to human health have been promulgated for centuries. Banana belongs the family Musaceae is cultivated all over the world. It composed of a significant amount of monomeric flavonoids, especially leucocyanidin, which is the active component possessing anti-ulcer action in indomethacin-induced ulcer model [60]. Banana skin extract administered with the doses of $0.3 \mathrm{ml} / 30 \mathrm{~g}$, $48 \mathrm{mg} / \mathrm{kg}$, and $100 \mathrm{mg} / \mathrm{kg}$ orally and tested against ulcer was induced by indomethacin in albino rats. As result, ulcer index was reduced compared to reference drug cimetidine $(100 \mathrm{mg} / \mathrm{kg}$ ) [61].

\section{Honey}

Honey is a natural non-plant food. Honey significantly reduced gastric acid when it was administered orally in combination with fenugreek seeds in rats against ethanol-induced ulcer model. It was observed that honey in combination with turmeric showed anti-ulcer activity in rats via antisecretory, antioxidant, and cellular protective mechanisms [62]. Honey polyphenols showed a protective effect in the gastrointestinal system [63]. The flavonoids present on honey exhibited anti-ulcer activity by increasing the level of mucosal prostaglandin and reducing of gastric acid secretion [64].

\section{Cucumber}

Cucumber belongs to the family Cucurbitaceae and contains Vitamin C, Vitamin K, linoleic acid, oleic acid, stearic acid, etc. It is cultivated in all over the world. The hydroalcoholic fruit extract of $C$. sativus was given orally against pylorus ligation, indomethacin-, and ethanol-induced ulcer models in rats, which reduced total acidity and ulcer index via prostaglandin synthesis or blockade of back diffusion of $\mathrm{H}^{+}$ions $[65,66]$.

\section{Cod liver oil}

Cod liver oil was effective in healing the development of chronic gastric ulcers induced by acetic acid and exerted protective effect against gastric ulcers induced by pylorus ligation, ethanol, stress, and indomethacin. Cod liver oil also exhibited protective effect against cysteamine-induced duodenal ulcers. As standard drugs, ranitidine and misoprostol were used [67]. In another study, cod liver oil was found to have a protective effect against ulcer induced by pyloric ligation, ethanol, and aspirin in rats when compared to standard drug omeprazole and sucralfate. The effect was assessed by the volume of gastric juice, ulcer scores, etc., in the ulcerated rat models. Cod liver oil exhibited a appreciable mucosal protection and anti-secretory action in all models [68].

\section{CONCLUSION}

From this current review, it can be concluded that majority of the products discussed above are from the natural sources. Moreover, during the past two decades, approximately $50 \%$ of new chemical moieties introduced as bioactive agents are from natural products. Literature survey also revealed that acid secretion is not the only cause of ulcer formation; there are also other causes such as less mucus secretion which is associated with the defense system of our body. That is why nowadays treatment of ulcer targets potentiating of the defensive system and also lowering of acid secretion. Different active constituents present in nature which play the role to increase in defensive mechanisms of our body against ulcer. Hence, it is important to segregate and characterize these active constituents from natural sources for carrying out their anti-ulcer activities and finally to establish the structure-activity relationships of these compounds. Furthermore, this review indicates that till date, clinical trials with anti-ulcer molecules are very limited. Therefore, analysis of the active 
constituents should be directed toward clinical relevance; otherwise, the benefits of research will not reach to the society.

\section{AUTHORS' CONTRIBUTIONS}

The authors contributed equally.

\section{CONFLICTS OF INTEREST}

The authors have declared that there is no conflict of interest.

\section{REFERENCES}

1. Vyawahare NS, Deshmukh VV, Gadkari MR, Kagathara VG. Plants with antiulcer activity. Pharmacogn Rev 2009;3:108-15.

2. Asali AM, Alghamdi MA, Fallatah SA, Alholaily WA, Aldandan RG, Alnosair AH, et al. Risk factors leading to peptic ulcer disease: Systematic review in literature. Int J Community Med Public Health 2018;5:4617-24.

3. Sung JJ, Kuipers EJ, El-Serag HB. Systematic review: The global incidence and prevalence of peptic ulcer disease. Aliment Pharmacol Ther 2009;29:938-46.

4. Malfertheiner P, Chan FK, McColl KE. Peptic ulcer disease. Lancet 2009;374:1449-61.

5. Velmishi V, Cekodhima G, Dervishi E, Cullufi P. Peptic ulcer disease in Albanian children: The role of Helicobacter pylori. Glob Adv Res J Microb 2014;3:127-32.

6. Testerman TL, Morris J. Beyond the stomach: An updated view of Helicobacter pylori pathogenesis, diagnosis, and treatment. World $\mathrm{J}$ Gastroenterol 2014;20:12781-808

7. Salih BA. Helicobacter pylori infection in developing countries: The burden for how long? Saudi J Gastroenterol 2009;15:201-7.

8. Abdul-Aziz KK. Comparative evaluation of the anti-ulcer activity of curcumin and omeprazole during the acute phase of gastric ulcer. Food Nutr Sci 2011;2:628-40.

9. Srinivas TL, Lakshmi SM, Shama SN, Reddy GK, Prasanna KR. Medicinal plants as anti-ulcer agents. J Pharmacogn Phytochem 2013;2:91-7.

10. Czekaj R, Majka J, Magierowska K, Sliwowski Z, Magierowski M, Pajdo R, et al. Mechanisms of curcumin-induced gastroprotection against ethanol-induced gastric mucosal lesions. J Gastroenterol 2018;53:618-30.

11. Tene M, Tane P, Kuiate JR, de Dieu Tamokou J, Connolly JD. Anthocleistenolide, a new rearranged nor-secoiridoid derivative from the stem bark of Anthocleista vogelii. Planta Med 2008;74:80-6.

12. Ateufack G, Nguelefack TB, Wabo HK, Tane P, Kamanyi A. Antiulcerogenic activity of 1-hydroxy-3, 7, 8-trimethoxyxanthone isolated from the methanol extract of Anthocleista vogelii PLANCH. In rats. Ulcers 2014;2014:1-6.

13. Ateufack G, Nguelefack TB, Wabo HK, Watcho P, Tane P, Kamanyi A. Antiulcer effects of the aqueous and organic extracts of the stem bark of Anthocleista vogelii. in rats. Pharm Biol 2006;44:1661-71.

14. Jung J, Lee JH, Bae KH, Jeong CS. Anti-gastric actions of eugenol and cinnamic acid isolated from Cinnamomi ramulus. Yakugaku Zasshi 2011;131:1103-10

15. Adisakwattana S, Sompong W, Meeprom A, Ngamukote S, YibchokAnun S. Cinnamic acid and its derivatives inhibit fructose-mediated protein glycation. Int J Mol Sci 2012;13:1778-89.

16. Oliveira Fde A, Andrade LN, de Sousa EB, de Sousa DP. Anti-ulcer activity of essential oil constituents. Molecules 2014;19:5717-47.

17. Derby R, Rohal P, Jackson C, Beutler A, Olsen C. Novel treatment of onychomycosis using over-the-counter mentholated ointment: A clinical case series. J Am Board Fam Med 2011;24:69-74.

18. Souza R, Cardoso M, Menezes C, Silva J, De Sousa D, Batista J, et al. Gastroprotective activity of $\alpha$-terpineol in two experimental models of gastric ulcer in rats. Daru 2011;19:277-81.

19. da Rocha ML, Oliveira LE, Patrício Santos CC, de Sousa DP, de Almeida RN, Araújo DA, et al. Antinociceptive and anti-inflammatory effects of the monoterpene $\alpha, \beta$-epoxy-carvone in mice. $J$ Nat Med 2013;67:743-9.

20. Siqueira BP, Menezes CT, Silva JP, Sousa DP, Batista JS. Antiulcer effect of epoxy-carvone. Rev Bras Farmacogn 2012;22:144-9.

21. Shah K, Shrivastava SK, Mishra P. Evaluation of mefenamic acid mutual prodrugs. Med Chem Res 2013;22:70-7

22. Rozza AL, Hiruma-Lima CA, Takahira RK, Padovani CR, Pellizzon CH. Effect of menthol in experimentally induced ulcers: Pathways of gastroprotection. Chem Biol Interact 2013;206:272-8.
23. Kodhati V, Vanga MR, Yellu NR. Synthesis and anti bacterial and anti-ulcer evaluation of new s-mannich bases of 4, 6-diaryl-3, 4-dihydropyrimidin-2 (1H)-thiones. J Korean Chem Soc 2013;57:234-40.

24. Gupta SP, Tiwari A, Upmanyu N, Garg G. Synthesis and evaluation of dihydropyrimidone derivatives as antiulcer agents. Curr Pharm Res 2014;5:1351-6.

25. Subudhi BB, Panda PK, Bhatta D. Synthesis and antiulcer activity study of 1, 4-dihydropyridines and their mannich bases with sulfanilamide. Ind J Chem 2009;48:725-8.

26. Swaminathan SR, Rajasekaran A, Manna PK. Dihyropyrimidinone-a versatile scaffold with diverse biological activity. J Pharm Sci Res 2016;8:741-6.

27. Ahmad Bhat M, Al-Omar MA, Naglah AM. Synthesis and in vivo antiulcer evaluation of some novel piperidine linked dihydropyrimidinone derivatives. J Enzyme Inhib Med Chem 2018;33:978-88.

28. Agarwal S, Sharma TR. Multiple biological activities of Aloe barbadensis (Aloe vera): An overview. Asian J Pharm Life Sci 2011;1:195-205.

29. Borra SK, Lagisetty RK, Mallela GR. Anti-ulcer effect of Aloe vera in non-steroidal anti-inflammatory drug induced peptic ulcers in rats. Afr J Pharm Pharmacol 2011;5:1867-71.

30. Keshavarzi Z, Rezapour TM, Vatanchian M, Zare Hesari M, Nabizade Haghighi H, Izanlu M, et al. The effects of aqueous extract of Aloe vera leaves on the gastric acid secretion and brain and intestinal water content following acetic acid- induced gastric ulcer in male rats. Avicenna $\mathrm{J}$ Phytomed 2014;4:137-43.

31. Neelima N, Sudhakar M, Patil MB, Lakshmi BV. Hypolipidemic activity and HPTLC analysis of Ixora coccinea L. Leaves. J Appl Pharm Sci 2011;1:172-80.

32. Zaman SU, Mirje MM, Ramabhimaiah S. Evaluation of the antiulcerogenic effect of Zingiber officinale (Ginger) root in rats. Int J Curr Microbiol Appl Sci 2014;3:347-54

33. Backon J. Ginger: Inhibition of thromboxane synthetase and stimulation of prostacyclin: Relevance for medicine and psychiatry. Med Hypotheses 1986;20:271-8.

34. Bandyopadhyay U, Biswas K, Sengupta A, Moitra P, Dutta P, Sarkar D, et al. Clinical studies on the effect of neem (Azadirachta indica) bark extract on gastric secretion and gastroduodenal ulcer. Life Sci 2004; $75: 2867-78$

35. Mohapatra BB, Nagoji KE. Anti-ulcer activity of aqueous and ethanolic leaf extract of neem (Azadirachta indica) in albino rats. J Pharm Res 2012:5:1571-82.

36. Taju G, Jayanthi M, Majeed SA. Evaluation of hepatoprotective and antioxidant activity of Psidium guajava leaf extract against acetaminophen induced liver injury in rats. Int J Toxicol Appl Pharmacol 2011;1:13-20.

37. Uduak EU, Timbuak JA, Musa SA, Ikyembe DT, Abdurrashid S, Hamman WO. Ulcerprotective effect of methanol extract of Psidium guajava leaves on ethanol induced gastric ulcer in adult Wistar rats. Asian J Med Sci 2012;4:75-8.

38. Livingston Raja NR, Sundar K. Psidium guajava Linn confers gastro protective effects on rats. Eur Rev Med Pharmacol Sci 2012;16:151-6.

39. Kaur R, Sen K. Antiulcer activity of hydroalcoholic extract of unripe fruit of Carica papaya in experimental rats. Int J Basic Clin Pharmacol 2017;6:432-40.

40. Imaga NO, Gbenle GO, Okochi VI, Akanbi SO, Edeoghon SO, Oigbochie V. Antisickling property of Carica papaya leaf extract. Afr J Biochem Res 2009;3:102-6.

41. Kishore DV, Jennifer P, Mini KV. Anti ulcer activity of methanolic and aqueous extracts of leaves of Sapindus trifoliatus. Linn. Int J Pharm Sci Rev Res 2011;6:25-7.

42. Vimala G, Gricilda Shoba F. A review on antiulcer activity of few Indian medicinal plants. Int J Microbiol 2014;2014:519590.

43. Sun XB, Matsumoto T, Yamada H. Anti-ulcer activity and mode of action of the polysaccharide fraction from the leaves of Panax ginseng. Planta Med 1992;58:432-5.

44. Sharma P, Prakash T, Kotresha D, Ansari MA, Sahrm UR, Kumar B, etal. Antiulcerogenic activity of Terminalia chebula fruit in experimentally induced ulcer in rats. Pharm Biol 2011;49:262-8.

45. Gupta PC. Biological and pharmacological properties of Terminalia chebula Retz. (Haritaki)-an overview. Int J Pharm Sci 2012;4 Suppl 3:62-8.

46. Ghangale GR, Mahale T, Jadhav ND. Evaluation of antiulcer activity of Ocimum sanctum in rats. Vet World 2009;2:465-6.

47. Siva M, Shanmugam KR, Shanmugam B, Subbaiah GV, Ravi S, Reddy S, et al. Ocimum sanctum: A review on the pharmacological properties. Int J Basic Clin Pharmacol 2016;5:558-65.

48. Venkateswararao C, Venkataramana K. A pharmacological review on 
natural antiulcer agents. J Glob Trends Pharm Sci 2013;4:1118-31.

49. Rao G, Sujatha D, Rupa VL, Priya ES, Rao KM, Venkateswarlu M. Study on anti-ulcer activity of Daucus carota juice. Res J Pharm Technol 2010;3:547-50.

50. Khatib N, Angel G, Nayna H, Joshi RK. Gastroprotective activity of the aqueous extract from the roots of Daucus carota L in rats. Int J Res Ayurveda Pharm 2010;1:112-9.

51. Hassan NA, Karunakaran R, Abdulmumin S. A review on the pharmacological and traditional properties of Mimosa pudica. Int $\mathrm{J}$ Pharm Pharm Sci 2019;11:12-6.

52. Eram S, Mujahid M, Bagga P, Ansari VA, Ahmad MA, Kumar A, et al. A review on phytopharmacological activity of Alpinia galanga. Int $\mathrm{J}$ Pharm Pharm Sci 2019;11:6-11.

53. Subramanian P, Nishan M. Biological activities of greater galangal, Alpinia galanga - a review. Res Rev J Bot Sci 2015;15-9.

54. Chudiwal AK, Jain DP, Somani RS. Alpinia galanga Willd- an overview on phyto-pharmacological properties. Indian J Nat Prod Resour 2010;1:143-9.

55. Chouni A, Paul S. A review on phytochemical and pharmacological potential of Alpinia galanga. Pharmacogn J 2018;10:9-15.

56. Choi YJ, Kim N, Lee JY, Nam RH, Chang H, Seo JH, et al. Protective effects of garlic extract, PMK-S005, against nonsteroidal antiinflammatory drugs-induced acute gastric damage in rats. Dig Dis Sci 2014;59:2927-34.

57. Mohammed A, Mohammed A, Prasad VS. Antiulcer activity of Allium sativum bulb juice in rats. Saudi Pharm J 2009;17:70-7.

58. El-Shinnawy NA, Abd-Elmageid SA, Alshailabi EM. Evaluation of antiulcer activity of indole-3-carbinol and/or omeprazole on aspirininduced gastric ulcer in rats. Toxicol Ind Health 2014;30:357-75.
59. Sudharameshwari K, Ayshwarya M. Evalution of antiulcerogenic activity of methanol extracts of Brassica oleracea Var. Capitata rubra on albino rat gastric ulceration. Asian J Pharm Clin Res 2017;10:314-7.

60. Das AK, Bigoniya P, Verma NK, Rana AC. Gastroprotective effect of Achyranthes aspera Linn. Leaf on rats. Asian Pac J Trop Med 2012;5:197-201.

61. Ulser T. Antiulcer activity of Musa paradisiaca (banana) tepal and skin extracts in ulcer induced albino mice. Malays J Anal Sci 2016;20:1203-16.

62. Adnyana IK, Sigit JI, Kusumawardani LA. Gastric ulcer healing effect of wild honey and its combination with turmeric (Curcuma domestica Val. rhizome on male wistar rats. J Chin Pharm Sci 2014;23:844-9.

63. Cianciosi D, Forbes-Hernández TY, Afrin S, Gasparrini M, ReboredoRodriguez P, Manna PP, et al. Phenolic compounds in honey and their associated health benefits: A review. Molecules 2018;23:E2322.

64. Almasaudi SB, El-Shitany NA, Abbas AT, Abdel-dayem UA, Ali SS, Al Jaouni SK, et al. Antioxidant, anti-inflammatory, and antiulcer potential of manuka honey against gastric ulcer in rats. Oxid Med Cell Longev 2016;2016:3643824.

65. Narra S, Nisha KS, Nagesh HS. Evaluations of antiulcer activity of hydroalcoholic fruit pulp extract of Cucumis sativus. Int J Pharm Sci Res 2015;6:4712-20.

66. Khandare RA, Gulecha VS, Mahajan MS. Evaluation of antiulcer activity of polyherbal formulation. Int J Pharm Res Dev 2009;1:1-6.

67. Khare S, Asad M, Dhamanigi SS, Prasad VS. Antiulcer activity of cod liver oil in rats. Indian J Pharmacol 2008;40:209-14.

68. Narkhede KP, Satapathy T, Pandit B. Protective effect of cod liver oil in experimentally induced gastric ulceration in rats. Res J Pharm Technol 2019;12:5-10 